\title{
FATTY ACIDS CONTENT OF KAHAI (CARYODENDRON ORINOCENSE KARST) SEEDS CULTIVATED IN AMAZONIAN OF ECUADOR
}

\author{
CARRILLO $\mathrm{W}^{1 *}$, GREFFA $\mathrm{J}^{2}$, VINUEZA $\mathrm{D}^{2}$, ÁLVAREZ $\mathrm{M}^{1}$, SILVA $\mathrm{M}^{1}$, CARPIO $\mathrm{C}^{1}$, MORALES $\mathrm{D}^{1}$
}

${ }^{1}$ Laboratory of Functional Foods, Faculty of Foods Science and Engineering, Technical University of Ambato, Avenue Los Chasquis y Rio Payamino, Campus Huachi, CP 1801334, Ambato, Ecuador. ${ }^{2}$ Polytechnic School of Chimborazo, Riobamba, Ecuador.

Email: wi.carrillo@uta.edu.ec

Received: 14 November 2016, Revised and Accepted: 03 May 2017

ABSTRACT

Objective: The aim of this study was to identify fatty acids present in a kahai oil sample cultivated in the Amazonian area of Ecuador.

Methods: Kahai oil was obtained from kahai seeds using the cold pressing method. Fatty acids analysis was carried out using the gas chromatography with a mass selective detector and using the database Library NIST 14.L to identify the compounds.

Results: Kahai seeds have $62.36 \%$ of total lipids. Kahai seeds have a high content of polyunsaturated fatty acids with $68.04 \%$ of linoleic acid and $2.90 \%$ of linolenic acid. Kahai oil has $18.59 \%$ of monounsaturated fatty acids of oleic acid. Kahai oil only has $7.0 \%$ of palmitic acid and $3.47 \%$ of stearic acid.

Conclusions: Kahai oil is a good source of polyunsaturated fatty acids omega 6 and has a good proportion of monounsaturated fatty acid omega 9. This oil can be used in cosmetic and pharmaceutical and functional foods for their composition of fatty acids. Kahai oil can be an alternative of crop to indigenous communities in the Amazonian area of Ecuador.

Keywords: Kahai, Caryodendron orinocense Karst, Fatty acids, Gas chromatography-mass spectrometer, Methyl ester.

(C) 2018 The Authors. Published by Innovare Academic Sciences Pvt Ltd. This is an open access article under the CC BY license (http://creativecommons. org/licenses/by/4. 0/) DOI: http://dx.doi.org/10.22159/ajpcr.2018.v11i2.16109

\section{INTRODUCTION}

Caryodendron orinocense Karst, named kahai, inchi, mani de arbor, and nuez de barinas in Ecuador, Colombia, and Venezuela. This plant belongs to the Euphorbiaceae family; it is cultivated to obtain kernel oil. There are very few studies about the composition of fatty acids of kahai oil [1]. Kahai fruit grows from November to June in the Amazonian region in Ecuador [2]. In the Amazonian region, there are a high number of plants with high lipid contents in the mesocarp and kernel seeds that can represent a good alternative to economy to the indigenous communities. Many crops can be exploited to this purpose as sacha inchi (Pluketenia volubilis) and Ungurahui (Oenocarpus bataua). Kahai seeds have a high content of lipids and proteins with approximately $29-50 \%$ of lipid content with a high content of polyunsaturated fatty acids, especially linoleic acid (omega 6) [1]. Radice et al., have reported a lipid content of $46.9 \%$ in kahai seeds out of which a value of $10.3 \%$ of palmitic acid (C16:0), 3.4\% of stearic acid (C18:0), and a value of $85.59 \%$ of linoleic acid (C18:2) [3]. Alfaro et al., have reported a value of $30 \%$ of lipid content in kahai seeds out of which a value of $9.52 \%$ of palmitic acid (C16:0), 2.17\% of stearic acid (C18:0), $11.80 \%$ of oleic acid (C18:1), 75.13\% corresponding to linoleic acid (C18:2), and $0.92 \%$ of linolenic acid (C18:3) [4]. This oil type has a good acceptation in the cosmetic and pharmaceutical industry to elaborate different formulations [5]. The aim of this work was to identify the fatty acids composition present in kahai (C. orinocense Karst) kernel from Ecuador using the gas chromatography-mass spectrometer (GC-MS).

\section{METHODS}

\section{Total lipid extraction}

Kahai walnuts were obtained in the Amazonian of Ecuador. Kahai oil sample was obtained from kahai walnuts using the cold pressed method. Oil was then stored at $4.0 \pm 2^{\circ} \mathrm{C}$. Oil extraction was conducted using a Soxhlet apparatus for approximately $5 \mathrm{~h}$ with hexane as solvent, with a solid-to-solvent ratio of $1 / 7 \mathrm{~m} / \mathrm{v}$. After the extraction process, the flask contents were filtered, and the liquid fraction containing the lipid extract and solvent was poured into a 250-mL flask of a rotary film evaporator to remove the solvent. The obtained oil was collected, evaporated under nitrogen, weighed, and stored in sealed amber glass vials at $-20^{\circ} \mathrm{C}$ until analysis [6].

\section{Methyl esters fatty acids (FAME)}

Methyl esters (FAME) were prepared from 3 to $5 \mathrm{mg}$ of total lipids using the two-step methylation method $(1 \% \mathrm{NaOCH} 3 / \mathrm{MeOH}$ followed by $5 \%$ $\mathrm{HCl} / \mathrm{MeOH}$ ); both steps were performed at $60^{\circ} \mathrm{C}, 20 \mathrm{~min}$ [7]. FAME were extracted with $6 \mathrm{ml}$ of hexane.

\section{Analysis of FAME from kahai oil by GC-MS}

The fatty acid composition of oil extracted from kahai walnut seeds was analyzed by injecting fatty acid methyl esters [8] into an Agilent Technologies 7980A system gas chromatography (Agilent, Santa Clara, CA) equipped with a mass selective detector 5977A GC/MSD, an auto-sampler 7693, column (60 m × $250 \mu \mathrm{m} \times 0.25 \mu \mathrm{m}$, DB-WAX Agilent 122-7062). The oven temperature was programmed as follows: From $80^{\circ} \mathrm{C}$; ramp 1: To $100^{\circ} \mathrm{C}$ at $20^{\circ} \mathrm{C} / \mathrm{min}$ during $1 \mathrm{~min}$; ramp 2: At $200^{\circ} \mathrm{C}$ at $25^{\circ} \mathrm{C} / \mathrm{min}$ during $10 \mathrm{~min}$; and ramp 3: At $250^{\circ} \mathrm{C}$ at $2^{\circ} \mathrm{C} / \mathrm{min}$. The injector and detector temperatures were set at $250^{\circ} \mathrm{C}$. Helium was used as carrier gas at a linear flow velocity of $1.4 \mathrm{~mL} / \mathrm{min}$.

Spectra were compared with the NIST 14.L library and the fatty acids mass spectra archive [9]. All GC analyses of the fatty acids were carried out in triplicate, and the results were expressed as the mean value \pm standard deviation.

\section{RESULTS AND DISCUSSION}

Methyl esters fatty acids (FAME) were analyzed with the GC-MS. The GC chromatogram of methyl esters fatty acids from kahai oil present five majoritarian peaks that were separated with a column Agilent DB-WAX 122-7062. These peaks were identified with the help of a 
spectrum of database NILTS 14.L. The quantification of fatty acids was obtained using the peak area ratio. Fig. 1 shows five abundant peaks with a good separation and definition, these peaks were identified C16:0 with a retention time of $19.321 \mathrm{~min}, \mathrm{C} 18: 0$ with a retention time of $25.955 \mathrm{~min}, \mathrm{C} 18: 1$ with a retention time of $26.856 \mathrm{~min}, \mathrm{C} 18: 2$ with a retention time of $28.628 \mathrm{~min}$, and finally C18:3 with a retention time of $31.092 \mathrm{~min}$.

The concentration of methyl esters fatty acids (FAME) was determined using the peak area ratio. Table 1 summarizes C16: With 7.0\% \pm 0.90 of fatty acid total content, C18: With $3.47 \% \pm 0.16$ of fatty acid total content, C18: 1 with $18.59 \% \pm 0.44$ of fatty acid total content, C18: 2 with $68.04 \% \pm 1.14$ of fatty acid total content, and C18:3 with $2.90 \% \pm 0.26$ of fatty acid total content of kahai oil. The total lipid of kahai seeds was of $62.36 \%$ of lipid in fresh weight (Table 1).

The mass spectrum of palmitic acid obtained from kahai oil is shown in Fig. 2. The identity and structures of these fatty acids were confirmed by the GC-MS method. Palmitic acid (C16:0) was identified using the mass spectrum with ions of mass/charge $(\mathrm{m} / \mathrm{z})$ between 55 and $270 \mathrm{~m} / \mathrm{z}$. In the previous range, the ions 74 and $87 \mathrm{~m} / \mathrm{z}$ were the most abundant in the mass spectrum.

Stearic acid (C18:0) was identified using the mass spectrum with ions with $\mathrm{m} / \mathrm{z}$ between 55 and $298 \mathrm{~m} / \mathrm{z}$. In the previous range, the ions 74 and $87 \mathrm{~m} / \mathrm{z}$ were the most abundant in the mass spectrum (Fig. 3).

Oleic acid (C18:1) was identified using the mass spectrum with ions $\mathrm{m} / \mathrm{z}$ between 55 and $296 \mathrm{~m} / \mathrm{z}$. In the previous range, the five ions with the highest abundance were the 55, 74, 83, 97, and $264 \mathrm{~m} / \mathrm{z}$ (Fig. 4).

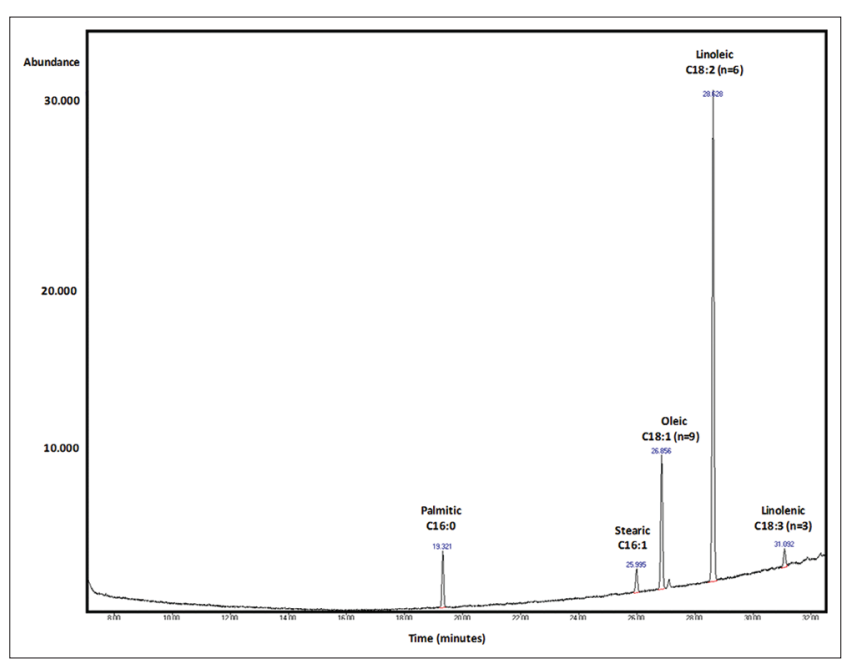

Fig. 1: Analysis by gas chromatography of methyl esters fatty acid (FAME) from kahai oil

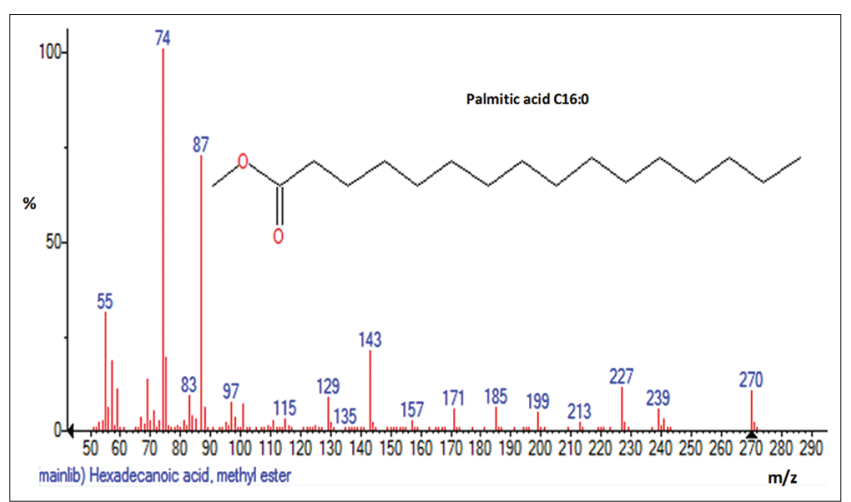

Fig. 2: Mass spectrum of palmitic acid from kahai oil
Linoleic acid (C18:2) was identified using the mass spectrum with ions $\mathrm{m} / \mathrm{z}$ between 55 and $294 \mathrm{~m} / \mathrm{z}$. In the previous range, the three most present ions were the 55, 67, 81, and $95 \mathrm{~m} / \mathrm{z}$ (Fig. 5).

When the kahai fatty acid composition is compared to some other common vegetable oils, it can be seen that olive oil has a high content of monounsaturated fatty acids, C18:1 named oleic acid with 77.6\% of oleic acid. It can be seen that kahai oil from Ecuador has a good content of monounsaturated fatty acids with a content of $18.59 \%$ of oleic acid. Kahai oil has also a high content of polyunsaturated fatty acids with $68.04 \%$ of linoleic acid. Olive oil contains few omega 6 and omega 3 fatty acids with $9.0 \%$ and $1.0 \%$, respectively, and macadamia oil contains $3.22 \%$ of omega 6 and $1.79 \%$ of omega 3 (Table 2). Kahai oil has a similar profile of fatty acids when it is compared to walnut Juglans regia with a high content of omega 6 and a good content of omega 9, both oils presenting a few content of omega $3[10,11]$. Walnut has been considered as a healthy food due to its capacity to reduce cardiovascular diseases risk. Food and Drug Administration

Table 1: Total lipid and fatty acids composition of tocte oil sample from Ecuador by GC-MS analysis and their percentage

\begin{tabular}{llll}
\hline $\begin{array}{l}\text { Retention } \\
\text { time }\end{array}$ & $\begin{array}{l}\text { Peak area } \\
\text { ratio \% }\end{array}$ & $\begin{array}{l}\text { Carbon number: Double } \\
\text { bound }\end{array}$ & $\begin{array}{l}\text { FAMEs } \\
\text { name }\end{array}$ \\
\hline $19.321 \mathrm{~min}$ & 7.00 & $\mathrm{C} 16: 0$ & Palmitic acid \\
$25.995 \mathrm{~min}$ & 3.47 & $\mathrm{C} 18: 0$ & $\begin{array}{l}\text { Stearic acid } \\
\text { Oleic acid }\end{array}$ \\
$26.856 \mathrm{~min}$ & 18.59 & $\Delta 9 \mathrm{C} 18: 1$ & Linoleic acid \\
$28.628 \mathrm{~min}$ & 68.04 & $\Delta 9,12 \mathrm{C} 18: 2$ & $\begin{array}{l}\text { Linolenic } \\
\text { acid }\end{array}$ \\
$31.092 \mathrm{~min}$ & 2.90 & $\Delta 9,12,15 \mathrm{C} 18: 3$ & \\
& & & \\
\hline
\end{tabular}

GC-MS: Gas chromatography-mass spectrometer

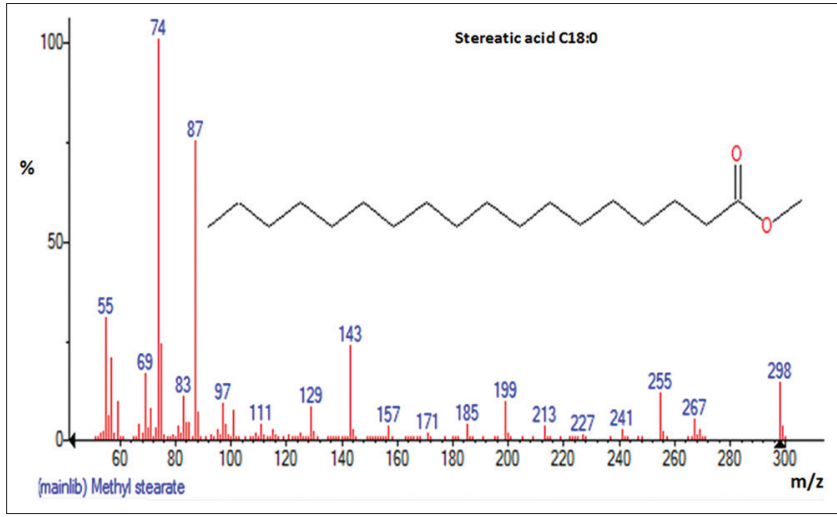

Fig. 3: Mass spectrum of stearic acid from kahai oil

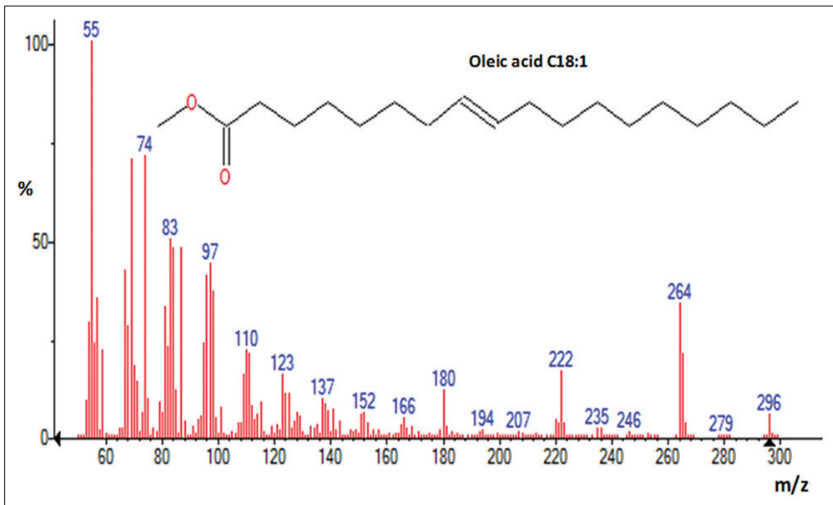

Fig. 4: Mass spectrum of oleic acid from kahai oil 
Table 2: Fatty acid composition (\%) of 10 vegetable oils

\begin{tabular}{|c|c|c|c|c|c|c|c|}
\hline References & Vegetal oil & C16:0 & C16:1 & C18:0 & C18:1 & C18:2 & C18:3 \\
\hline$[18,19]$ & Olive oil & 13.8 & 1.4 & 2.8 & 71.6 & 9.00 & 1.0 \\
\hline [18] & Sunflower oil & 5.2 & 0.1 & 3.7 & 33.7 & 56.5 & 0.0 \\
\hline [18] & Palm oil & 44.8 & 0.0 & 4.6 & 38.9 & 9.5 & 0.4 \\
\hline [18] & Soybean oil & 10.1 & 0.0 & 4.3 & 22.3 & 53.7 & 8.1 \\
\hline [18] & Corn oil & 11.6 & 0.0 & 2.5 & 38.7 & 44.7 & 1.4 \\
\hline [19] & Sacha inchi oil & 3.98 & 0.0 & 3.12 & 8.58 & 34.98 & 47.04 \\
\hline [20] & Sambo oil & 9.33 & 0.0 & 6.84 & 41.36 & 33.98 & 0.0 \\
\hline \multirow[t]{2}{*}{ [22] } & Walnut Juglans regia & 7.80 & ND & 2.30 & 23.10 & 66.54 & ND \\
\hline & Kahai oil & 7.0 & 0.0 & 3.47 & 18.59 & 68.04 & 2.90 \\
\hline
\end{tabular}

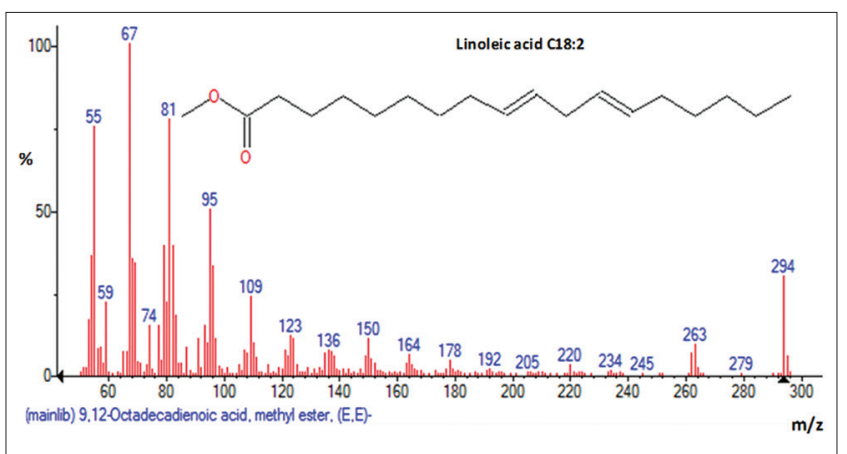

Fig. 5: Mass spectrum of linoleic acid from kahai oil

of US in the year 2004 have accepted the claim about the consume of walnuts to reduce and prevent cardiovascular diseases. It is also known that walnut inclusion in diets brings benefits in the human health for their good lipid composition [12]. Around 1 billion people are affected by hypertension disease and 7 million annual deaths are attributed to this disease. The type 2 diabetes mellitus is a disease rapidly increasing in the world and is directly implicated in the risk of cardiovascular diseases. Fortunately, hypertension and diabetes prevention trials in high-risk groups have shown that weight loss among obese individuals, physical activity, adoption of a diet rich in fresh fruit, vegetables, potassium, and a reduced sodium content may reduce the incidence of hypertension. Nuts have long been part of human diet since pre-agricultural times, supply food rich in a number of nutrients, and phytochemicals components that may reduce risks of cardiovascular disease (diabetes and hypertension) [13,14]. Nuts have saturated fatty acids and high in monounsaturated and polyunsaturated fats omega 9: Oleic acid, omega 6: Linoleic acid, and omega 3: Linolenic acid. Nuts are also a good source of vegetable protein, fiber, phytosterols, polyphenols, vitamins, and minerals [15]. These bioactive compounds can serve as antioxidants, are antiinflammatory, and may improve insulin resistance, and thus nuts may lower diabetes and hypertension risk. Nuts protein can be a source of bioactive peptides that can be free after human digestion. When people include nuts in their diet, they can reduce and prevent cardiovascular diseases $[16,17]$.

\section{ACKNOWLEDGMENTS}

This study was supported by Universidad Técnica de Ambato, Ecuador (Project CPU-1373-2014-UTA) and Project Canje de Deuda EspañaEcuador. This work has been reviewed in the English edition by Emilio Labrador.

\section{AUTHOR CONTRIBUTIONS}

Greffa J, Vinueza D, Carpio C, Morales D and Carrillo W conceived and designed the experiments. Silva M and Alvarez M performed the gas chromatography analyses. Carrillo $\mathrm{W}$ wrote the paper.

\section{CONFLICT OF INTERESTS}

The authors declare no conflict of interest.

\section{REFERENCES}

1. Alfaro Mde J, Alvarez I, El Khor S, de Padilla FC. Functional properties of a protein product from Caryodendron orinocense (Barinas nut). Arch Latinoam Nutr 2004;54:223-8.

2. Perez RM, Alfaro MJ, Padilla FC. Evaluation of "nuez Barinas" (Caryondredon orinocense) oil for possible use in cosmetic. Int $\mathrm{J}$ Cosmetic Sci 1999;21:151-8.

3. Radice M, Viafara D, Neill D, Asanza M, Sacchetti G, Guerrini A, et al. Chemical characterization and antioxidant activity of Amazonian (Ecuador) Caryodendron orinocense karst. And Bactris gasipaes kunth seed oils. J Oleo Sci 2014;63:1243-50.

4. Alfaro MJ, Padilla FC. Evaluation of 'nuez de Barinas' (Caryodendron orinocense) oil for possible use in cosmetic. Int J Cosmetic Sci 1999;21:151-8.

5. Alfaro Mde J, de Padilla FC. Physico-chemical characteristics of the Barinas nut (Caryodendron orinocense karst. Euphorbiaceae) crude oil. Arch Latinoam Nutr 1994;44:172-5.

6. Stevenson DG, Eller FJ, Wang L, Jane JL, Wang T, Inglett GE, et al. Oil and tocopherol content and composition of pumpkin seed oil in 12 cultivars. J Agric Food Chem 2007;55:4005-13.

7. Gutiérrez LF, Rosada LM, Jiménez A. Chemical composition of sacha inchi (Plukenetia volubilis L.) seeds and characteristics of their lipid fraction. Grasas Aceites 2011;62:76-83.

8. House SD, Larson PA, Johnson RR, De Vries JW, Martin DL. Gas chromatographic determination of total fat extracted from food samples using hydrolysis in the presence of antioxidant. J Assoc Off Anal Chem 1994;77:960-5.

9. Christie WW. Mass Spectrometry of Fatty Acid Derivatives; 2014. Available from: http://www.lipidlibrary.aocs.org/ms/masspec.html. [Last accessed on 2017 Mar 14].

10. Amaral JS, Casal S, Pereira JA, Seabra RM, Oliveira BP. Determination of sterol and fatty acid compositions, oxidative stability, and nutritional value of six walnuts (Juglans regia L.) cultivars grown in Portugal. J Agric Food Chem 2003;51:7698-702.

11. Mao X, Hua Y, Chen G. Chemical composition, molecular weight distribution, secondary structure and effect of $\mathrm{NaCl}$ on functional properties of walnut (Juglans regia $\mathrm{L}$ ) protein isolates and concentrates. J Food Sci Technol 2014;5:1473-82.

12. Fanali $\mathrm{C}$, Dugo L, Cacciola F, Beccaria M, Grasso S, Dachà M, et al. Chemical characterization of sacha inchi (Plukenetia volubilis L.) oil. J Agric Food Chem 2011;59:13043-9.

13. FDA. Qualified Health Claims: Letter of Enforcement Discretion - Walnuts and Coronary Heart Disease. Washington, DC: Food and Drug Administration; 2014

14. Hardy G. Nutraceuticals and functional foods: Introduction and meaning. Nutrition 2000;16:688-9.

15. Perugu S, Vemula R, Rao MV. Walnut pedunculagin a probable serm for breast cancer treatment. Int J Pharm Pharm Sci 2014;7:233-5.

16. Lloyd-Jones DM, Hong Y, Labarthe D, Mozaffarian D, Appel LJ, Van Horn L, et al. Defining and setting national goals for cardiovascular health promotion and disease reduction: The American heart association's strategic impact goal through 2020 and beyond. Circulation 2010;121:586-613.

17. Dyer JM, Stymne S, Green AG, Carlsson AS. High value oils in plants. 
Plant J 2008;54:640-55.

18. Dhifi W, Khedher MB, Bellili S, Sadaka C, Wakim L, El Beyrouthy M, et al. Effects of olive drying and storage on the oxidative status, aroma, chlorophyll and fatty acids composition of olive oil. Int J Pharm Pharm Sci 2014;7:102-8.

19. Carrillo W, Quinteros MF, Carpio C, Morales D, Vasquez G, Alvarez M, et al. Identification of fatty acids in sacha inchi oil (Pluketenia volubilis L.) from Ecuador. Asian J Pharm Clin Res 2017;10:303-6.

20. Carrillo W, Carrillo C, Carpio C, Morales D, Vilcacundo E, Alvarez M, et al. Characterization of fatty acids in sambo oil (Cucurbita ficifolia L.) from Ecuador. Asian J Pharm Clin Res 2017;10:303-6.

21. Carrillo W, Carpio C, Morales D, Vilcacundo E, Alvarez M. Fatty acids composition in Macadamia seeds oil (Macadamia integrifolia) from Ecuador. Asian J Pharm Clin Res 2017;10:303-6.

22. Iqbal M, Bhatti IA, Shahid M, Nisar J. Physicochemical characterization, microbial decontamination and shelf life analysis of walnut (Juglans regia $\mathrm{L}$ ) oil extracted from gamma radiation treated seeds. Int Soc Biocatal Agric Biotechnol 2016;6:116-22. 